\title{
HUBUNGAN TINGKAT KECERDASAN SPIRITUAL DENGAN KEDISIPLINAN SANTRI DALAM MENJALANKAN PERATURAN PONDOK PESANTREN AL-MASRURIYYAH TEBUIRENG DIWEK JOMBANG
}

\author{
Qo'id Afifudin*1 \\ Program Studi Pendidikan Agama Islam \\ Universitas KH. A. Wahab Hasbullah \\ Email: qoidafifudin@gmail.com \\ Waslah $^{2}$ \\ Program Studi Pendidikan Agama Islam \\ Universitas KH. A. Wahab Hasbullah \\ Email: waslah@unwaha.ac.id
}

\begin{abstract}
This research is based on the spiritual intelligence possessed by the students. Santri is known as a good character individual, this is supported by islamic boarding school fasilities. Students get a good education, such as politeness, discipline, friendliness, courtesy and many other good qualities that are obtained by the students at Islamic boarding schools. However, a discipline has not been fully reflected in santri of Al-Masruriyyah. There were still some students who did not participate in the activity when the activity was held the coaches and administrators have conditioned the students in each room, but they do not leave to participate in the activity. The purpose of this study was to determine the level of spiritual intelligence and discipline of students in carrying out the rules at the Al-Masruriyyah boarding school, as well as to analyze the influence of the level of spiritual intelligence and discipline of the students in the boarding school. The approach used in this research is a quantitative approach. Data collection using questionnaires, interviews and documentation. For research data analysis, researchers used product moment correlation analysis to obtain the results of the predetermined hypotheses. The research shows that the Spiritual Intelligence of the Santri has high criteria, the discipline of the students in carrying out the rules is obtained by a high criterion, and the rcount with a number of 0,556 is greater than the $r$ table, so that $\mathrm{Ha}$ is accepted, namely "there is a relationship between the level of spiritual intelligence and the discipline of students in implementing the rules of the Al-Islamic Boarding School. Masruriyyah Tebuireng Diwek Jombang ".
\end{abstract}

Keywords: Spiritual Intelligence; Discipline and Islamic boarding school 


\title{
Qo'id Afifudin, Waslah.
}

\begin{abstract}
Abstrak
Penelitian ini didasari oleh kecerdasan spiritual yang dimiliki santri. Santri di pandang sebagai individu yang mempunyai karekter yang baik, hal tersebut didukung dengan tinggalnya santri di lingkungan pondok pesantren. Di pondok pesanren santri memperoleh pendidikan yang baik, seperti kesopanan, kedisiplinan, keramahan, kesopanan dan masih banyak sifat baik lainya yang diperoleh santri di pondok pesantren. Namun kedisiplinan santri belum sepenuhnya tercermin pada santri Al-Masruriyyah. Masih ada beberapa santri saat kegiatan dilaksanakan tidak mengikuti kegiatan. Pembina dan pengurus sudah melakukan pengkondisian santri di setiap kamar, tetapi mereka tidak berangkat untuk mengikuti kegiatan. Tujuan dari penelitian ini adalah untuk mengetahui tingkat kecerdasan spiritual dan kedisiplinan santri dalam menjalankan peraturan di pondok Al-Masruriyyah, serta untuk menganalisis ada atau tidaknya pengaruh tingkat kecerdasan spiritual dan kedisiplinan santri di pondok pesantren tersebut. Pendekatan yang digunakan dalam penelitian ini adalah pendekatan kuantitatif. Pengumpulan data menggunakan angket, wawancara dan dokumentasi. Untuk analisis data penelitian, peneliti menggunakan analisis korelasi product moment untuk mendapatkan hasil dari hipotesis yang telah ditetapkan. Penelitian menunjukkan bahwa Kecerdasan Spiritual Santri diperoleh kriteria tinggi, kedisiplinan santri dalam menjalankan peraturan diperoleh kriteria tinggi, serta rhitung dengan jumlah 0,556 lebih besar dari rtabel, sehingga Ha diterima yakni "terdapat hubungan antara tingkat kecerdasan spiritual dengan kedisiplinan santri dalam menjalankan peraturan Pondok Pesantren Al-Masruriyyah Tebuireng Diwek Jombang".
\end{abstract}

Kata kunci: Kecerdasan Spiritual; Kedisiplinan dan Pondok Pesantren

\section{A. PENDAHULUAN}

Pramoedya Ananta Toer berkata bahwa pelajar harus belajar berlaku adil sudah sejak dalam pikiran, apalagi dalam perbuatan. Dalam penegasan yang singkat ini terkandung makna bahwa perbuatan manusia hendaknya sesuai dengan martabatnya. Manusia bertanggung jawab terhadap setiap pebuatan yang dilakukannya. Perbuatan manusia mempunyai asal atau penyebab di dalam kehendak bebas dan rasionalitasnya. Oleh karena itu akumulasi serangkaian tindakan yang baik akan menimbulkan kebiasaan atau habitus yang baik. 
Rasulullah SAW bersabda, bahwa dalam tubuh manusia terdapat hati yang apabila baik maka baiklah seluruh tubuh manusia dan apabila rusak maka rusaklah seluruh tubuh manusia. ${ }^{1}$

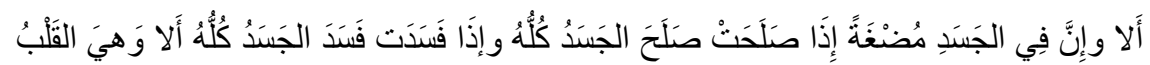

Selain kecerdasan intelektual atau intellectual quotient (IQ) masih ada

kecerdasan lain yang mempengaruhi kesuksesan seseorang, kecerdasan tersebut adalah kecerdasan emosional (emotional quotient atau EQ) dan kecerdasan spiritual (spiritual quotient atau SQ). Kecerdasan spiritual atau spiritual quotient (SQ) juga memiliki peranan penting dalam kesuksesan seseorang. ${ }^{2}$

Kecerdasan Spiritual adalah kecerdasan yang bisa digunakan manusia untuk membimbing dan menyelesaikan persoalan-persoalan makna dan nilai, untuk menempatkan perilaku dan hidup manusia pada kontek makna yang lebih luas dan lebih kaya, kecerdasan untuk menilai bahwa perilaku seseorang lebih bermanfaat dibandingkan dengan yang lain. ${ }^{3}$

Santri dipandang memiliki kecerdasan spiritual. Oleh karena itu, santri dianggap memiliki karakter yang baik, karena hal itu didukung oleh lingkungan di pondok pesantren. Di masyarakat santri seringkali dijadikan suri tauladan oleh masyarakat dimana santri itu bertempat. Di pondok pesanren santri memperoleh

\footnotetext{
${ }^{1}$ Muhammad Kusni Mubarok dan Waslah, "Hubungan Tingkat Kecerdasan Spiritual Dengan Kesadaran Santri Dalam Menjalankan Peraturan Pondok Pesantren Al Muhajirin 3 Bahrul 'Ulum Tambakberas Jombang,” Journal of Education and Management Studies Universitas KH. A. Wahab Hasbullah Jombang Vol. 3, no. 4 (2020): 42.

2 Rizky Sulastyaningrum, Trisno Martono, dan Budi Wahyono, "Pengaruh Kecerdasan Intelektual, Kecerdasan Emosional, dan Kecerdasan Spiritual Terhadap Prestasi Belajar Mata Pelajaran Ekonomi Pada Peserta Didik Kelas XI IPS di SMA Negeri 1 Bulu Tahun Ajaran 2017/2018," Jurnal Pendidikan Bisnis dan Ekonomi 4, no. 2 (2019): 3-4.

${ }^{3}$ Ulfah Rahmawati, "Pengembangan Kecerdasan Spiritual Santri: Studi terhadap Kegiatan Keagamaan di Rumah TahfizQu Deresan Putri Yogyakarta," Jurnal Penelitian Vol. 10, no. 1 (2016): 105-106.
} 


\section{Qo'id Afifudin, Waslah.}

pendidikan yang baik, seperti kesopanan, kedisiplinan, keramahan, kesopanan dan masih banyak sifat baik lainya yang diperoleh santri di pondok pesantren.4

\section{Kecerdasan Spiritual}

Kecerdasan spiritual atau spiritual quotient (SQ) adalah kecerdasan jiwa, merupakan kecerdasan yang bisa membantu kita untuk menyembuhkan dan membangun diri kita secara utuh. SQ adalah kecerdaan yang terdapat di bagian diri yang dalam, berhubungan dengan kearifan di luar ego atau pikiran sadar. SQ adalah kesadaran yang digunakan untuk mengakui nilai-nilai yang ada dan secara kreatif menemukan nilai-nilai baru. SQ tidak bertumpu pada budaya maupun nilai. SQ memelopori seluruh nilai-nilai spesifik dan budaya manapun. ${ }^{5}$

\section{Kedisiplinan}

Dalam Kamus Bahasa Indonesia disiplin adalah tata tertib, ketaatan pada peraturan. ${ }^{6}$ Disiplin adalah keadaan tertib, teratur, dimana pendidik dan peserta didik patuh terhadap segala peraturan atau tata tertib yang ada tanpa paksaan. Disiplin merupakan hal yang sangat penting, karena tanpa sesuatu kelompok akan bias tercapai tujuan akhirnya. ${ }^{7}$

\section{Peraturan Pondok Pesantren}

\footnotetext{
4 Mubarok dan Waslah, "Hubungan Tingkat Kecerdasan Spiritual Dengan Kesadaran Santri Dalam Menjalankan Peraturan Pondok Pesantren Al Muhajirin 3 Bahrul 'Ulum Tambakberas Jombang,” 42.

${ }^{5}$ Danah Zohar dan Ian Marshall, SQ Kecerdasan Spiritual, Cet. XI. (Bandung: PT. Mizan Pustaka, 2007), $8-9$.

${ }^{6}$ Departemen Pendidikan Nasional, Kamus Bahasa Indonesia (Jakarta: Pusat Bahasa, 2008), 358.

${ }^{7}$ Aldo Redho Syam, "Manajemen Pendidikan Kedisiplinan Santri Di Pondok Pesantren (Studi Kasus Di Pondok Modern Darussalam Gontor Ponorogo)”(UIN Maulana Malik Ibrahim, 2015), 26.
} 
Dalam Kamus Bahasa Indonesia peraturan merupakan tatanan (petunjuk, kaidah, ketentuan) yang dibuat untuk mengatur. ${ }^{8}$ Peraturan adalah sesuatu yang harus dipatuhi sesuai dengan perintah yang telah diputuskan yang harus dilakukan oleh siswa, apabila siswa melakukan pelanggaran maka siswa akan mendapatkan sanksi. ${ }^{9}$ Pondok Pesantren merupakan lembaga pendidikan yang bercorak keIslaman, di mana merupakan suatu elemen penting dari kehidupan seseorang dan aspek strategis bagi suatu Negara. ${ }^{10}$

Di Pondok Pesantren Al-Masruriyyah Tebuireng Diwek Jombang khususnya, kedisiplinan merupakan hal harus dimiliki oleh seorang santri. Sehingga dalam melaksanakan segala kegiatan pondok pesantren supaya santri memiliki kehendak atas diri sendiri dalam menjalankan peraturan dan melaksanakan segala kegiatan yang ada di pondok pesantren. Peneliti menjadikan Pondok Pesantren Al-Masruriyyah Tebuireng Diwek Jombang sebagai objek penelitian, karena santriwati Pondok Pesantren Al-Masruriyyah Tebuireng Diwek Jombang dalam melaksanakan peraturan pondok pesantren mempunyai tingkat kedisiplinan yang berbeda-beda, seperti ada santri saat kegiatan akan dilaksanakan tidak berangkat mengikuti kegiatan dan ada santriwati yang mengikuti kegiatan, sedangkan pengurus pondok pesantren sudah melakukan pengkondisian santri di setiap kamar. Jadi antara santriwati yang satu dengan

\footnotetext{
${ }^{8}$ Nasional, Kamus Bahasa Indonesia, 104.

9 M. Okta Riyanto, "Peraturan Pondok Pesantren," 2015, diakses 3 Maret 2021, http://oktamansabo.blogspot.com/2015/06/peraturan-pondok-pesantren.html.

${ }^{10}$ Syaiful Sagala, "Manajemen Dan Kepemimpinan Pendidikan Pondok Pesantren," Jurnal Tarbiyah 22, no. 2 (2015): 209.
} 


\section{Qo'id Afifudin, Waslah.}

yang lainnya dalam hal kedisiplinan dalam menjalankan peraturan pondok pesantren memiliki kualitas yang berbeda-beda. Berbeda kedisiplinan santriwati, maka pengaruh kecerdasan spiritual yang dialami oleh santriwati juga berbeda.

Peneliti juga mengemukakan beberapa penelitian terdahulu, dengan tujuan agar terhindarnya aspek-aspek yang sama dengan penelitian yang peneliti lakukan. Pertama, Hubungan Kecerdasan Spiritual Dan Dukungan Orang Tua Dengan Kesiapan Siswa Kelas IX Dalam Menghadapi Ujian Nasional Berbasis Komputer (UNBK) Tahun 2020 di MTsN 1 Kab. Madiun oleh Ulfa Ummul Maghfiroh pada tahun 2020, Kedua, Hubungan Antara Kecerdasan Spiritual Dengan Kepribadian Santri Pondok Pesantren Alhidayah Karangsuci Purwokerto oleh Rifangatul Mahmudah pada tahun 2016. Ketiga, Pengaruh Tingkat Kedisiplinan Shalat Fardlu Terhadap Kecerdasan Spiritual Santri Pondok Pesantren Al-Hikmah Tugurejo Tugu Semarang Tahun 2015 oleh Indana Mashlahatur Rifqoh pada tahun 2015. Pada penelitian terdahulu meneliti hubungan kecerdasan spiritual dengan aspek yang berbeda yang peneliti gunakan. Aspek yang dipakai dalam penelitian ini yaitu kedisplinan, selain itu obyek yang diteliti adalah Santri Pondok Pesanttren Al-Masruriyyah Tebuireng Diwek Jombang. Peneliti menyertakan penelitian terdahulu untuk melengkapi informasi mengenai penelitian kecerdasan spiritual di pondok pesantren.

Berdasarkan uraian di atas, maka dilakukan penelitian dengan tujuan untuk mendeskripsikan tentang kecerdasan spiritual santri, untuk 
mendeskripsikan tentang kedisiplinan santri dalam menjalankan peraturan pondok pesantren dan untuk menganalisis ada atau tidaknya hubungan antara tingkat kecerdasan spiritual dengan kedisiplinan santri dalam menjalankan peraturan Pondok Pesantren Al-Masruriyyah Tebuireng Diwek Jombang.

\section{B. METODE}

Pada penelitian ini, metode penelitian yang penulis gunakan merupakan jenis penelitian kuantitatif. Penarikan data Penelitian Kuantitatif berlandasakan pada pada filsafat positivisme, digunakan untuk meneliti pada populasi atau sampel tertentu. ${ }^{11}$

Populasi dalam penelitian ini adalah seluruh santri Pondok Pesantren AlMasruriyyah Tebuireng Diwek Jombang dengan jumlah 170 santri. Sedangkan sampel dalam penelitian ini diambil dengan menggunakan teknik Simple Random Sampling. Dalam penelitian, semakin besar sampel semakin baik hasil yang diperoleh. ${ }^{12}$ Dalam penelitian ini, sampel yang akan peneliti ambil berjumlah 87 santri. Teknik pengumpulan data menggunakan wawancara, kuesioner (angket) dan dokumentasi.

Penelitian ini terdiri dari 2 variabel yaitu Kecerdasan Spiritual $(X)$ dan Kedisiplinan Santri dalam menjalankan Peraturan (Y). Teknik analisis data yang digunakan dalam penelitian ini adalah uji validitas, uji reliabilitas dan uji hipotesis dengan menggunakan rumus korelasi product moment. Pengolahan

\footnotetext{
${ }^{11}$ Sugiyono, Metode Penelitian Pendidikan Pendekatan Kuantitatif, Kualitatif, dan R\&D, Cet. Ke 22. (Bandung: CV. Alfabeta, 2015), 14.

${ }^{12}$ Hamid Darmadi, Metode Penelitian Pendidikan (Bandung: CV. Alfabeta, 2011), 51.
} 


\section{Qo'id Afifudin, Waslah.}

data dalam penelitian ini juga menggunakan aplikasi IBM SPSS versi 26.00 for windows.

\section{HASIL PENELITIAN}

\section{Analisis Jawaban Responden}

Pada langkah ini digunakan untuk menguraikan data yang telah diperoleh dari penyebaran angket kepada 87 responden ke dalam tabel mean (rata-rata), sehingga dalam tabel tersebut akan dipoeroleh hasil dari variabel $\mathrm{X}$ (Kecerdasan Spiritual) dan Variabel Y (Kedisiplinan Santri dalam menjalankan Peraturan).

\section{- Kecerdasan Spiritual (Variabel X)}

Hasil yeng peneliti dapatkan dari semua jawaban responden sebesar 3121. Selanjutnya bias diketahui hasil rata-rata dari variabel X (Kecerdasan Spiritual) dengan penghitungan sebagai berikut:

Diketahui:

$$
\Sigma x=3121 \quad \mathrm{~N} \quad=87
$$

Jadi, $\mathrm{M}=\frac{\sum x}{N}=\frac{3121}{87}=35,9$

Berdasarkan perhitungan dengan rumus Mean di atas dapat disimpulkan bahwa rata-rata dari kecerdasan spiritual berada pada skor antara 30 - 40 dengan kriteria tinggi.

- Kedisiplinan Santri dalam menjalankan Peraturan (Variabel Y) 
Hasil yang peneliti dapatkan dari semua jawaban responden sebesar 3056. Selanjutnya bias diketahui hasil rata-rata dari variabel Y (Kedisiplinan Santri dalam menjalankan Peraturan) dengan penghitungan sebagai berikut:

Diketahui:

$$
\begin{aligned}
& \Sigma y \quad=3056 \\
& \mathrm{~N} \quad=87 \\
& \text { Jadi, } \mathrm{M}=\frac{\sum y}{N}=\frac{3056}{87}=35,1
\end{aligned}
$$

Berdasarkan perhitungan dengan rumus Mean di atas dapat disimpulkan bahwa rata-rata dari kedisiplinan santri dalam menjalankan peraturan berada pada skor antara 30 - 40 dengan kriteria tinggi.

\section{Uji Validitas}

Hasil penelitian dikatakan valid apabila data yang tekumpul terdapat kesamaan dengan objek yang diteliti. Instrumen dikatakan valid jika alat ukur yang digunakan untuk mendapatkan data itu valid. Instrumen penelitian yang valid bisa digunakan untuk mengukur apa yang seharusnya diukur dalam penelitian. ${ }^{13}$ Adapun kisi-kisi instrumen yang peneliti gunakan dalam penelitian ini sebagai berikut:

Tabel 1. Kisi-Kisi Instrumen

\begin{tabular}{|l|l|c|}
\hline \multicolumn{1}{|c|}{ Variabel } & \multicolumn{1}{|c|}{ Indikator } & No. Butir \\
\hline $\begin{array}{l}\text { Variabel X } \\
\text { (Kecerdasan } \\
\text { Spiritual) }\end{array}$ & Mampu menyesuaikan diri dengan lingkungan & $1,2,3$ \\
\cline { 2 - 3 } & Mampu mendorong dirinya untuk instropeksi & $4,5,6,7$ \\
\hline
\end{tabular}

${ }^{13}$ Sugiyono, Metode Penelitian Pendidikan Pendekatan Kuantitatif, Kualitatif, dan R\&D, 172-173. 


\section{Qo'id Afifudin, Waslah.}

\begin{tabular}{|l|l|c|}
\hline & diri & $8,9,10$ \\
\cline { 2 - 3 } & Tujuan hidup yang telah pasti & $1,2,3$ \\
\hline $\begin{array}{l}\text { Variabel Y } \\
\text { (Kedisiplinan santri } \\
\text { dalam menjalankan } \\
\text { peraturan) }\end{array}$ & $\begin{array}{l}\text { Sikap taat dan tertib terhadap peraturan } \\
\text { pondok pesantren }\end{array}$ & $\begin{array}{l}\text { Sikap taat dan teratur dalam mengikuti } \\
\text { kegiatan di pondok pesantren }\end{array}$ \\
\cline { 2 - 3 } & $\begin{array}{l}\text { Kesungguhan hati dalam menjalankan } \\
\text { peraturan di pondok pesantren }\end{array}$ & $8,5,6,7$ \\
\hline
\end{tabular}

Berikut tabel hasil analisis uji validitas yang penelliti dapatkan, uji validitas ini menggunakan aplikasi IDM SPSS versi 26.0 for windows.

Tabel 2. Hasil Pengujian Validitas Instrumen

\begin{tabular}{|c|l|l|l|l|l|}
\hline No & \multicolumn{1}{|c|}{ Pernyataan } & $R_{\text {Hitung }}$ & $R_{\text {Tabel }}$ & Keterangan \\
\hline \multicolumn{5}{|c|}{ Kecerdasan Spiritual (Variabel X) } \\
\hline 1 & $\begin{array}{l}\text { Saya cepat beradaptasi dengan lingkungan } \\
\text { dan kegiatan pondok pesantren }\end{array}$ & 0,561 & 0,210 & Valid \\
\hline 2 & $\begin{array}{l}\text { Saya berbusana rapi dan sopan sesuai } \\
\text { dengan peraturan yang ditetapkan di } \\
\text { pondok pesantren }\end{array}$ & 0,542 & 0,210 & Valid \\
\hline 3 & $\begin{array}{l}\text { Saya menjaga ucapan dan perkataan yang } \\
\text { saya bicarakan }\end{array}$ & 0,555 & 0,210 & Valid \\
\hline 4 & $\begin{array}{l}\text { Saya memiliki keinginan untuk melakukan } \\
\text { hal yang bermanfaat untuk orang lain. }\end{array}$ & 0,479 & 0,210 & Valid \\
\hline 5 & $\begin{array}{l}\text { Saya merasa berdosa apabila berbohong } \\
\text { kepada orang tua, guru, dan teman }\end{array}$ & 0,527 & 0,210 & Valid \\
\hline 6 & $\begin{array}{l}\text { Ketika tertimpa musibah, saya tetap } \\
\text { bersamangat untuk beribadah }\end{array}$ & 0,695 & 0,210 & Valid \\
\hline 7 & Saya mengambil hikmah dari setiap masalah & 0,614 & 0,210 & Valid \\
\hline 8 & $\begin{array}{l}\text { Saya cenderung melihat kebenaran dan } \\
\text { fakta yang terjadi }\end{array}$ & 0,313 & 0,210 & Valid \\
\hline 9 & $\begin{array}{l}\text { Ketika ada waktu luang saya gunakan untuk } \\
\text { belajar }\end{array}$ & 0,631 & 0,210 & Valid \\
\hline 10 & $\begin{array}{l}\text { Saya bisa membagi kapan waktu belajar dan } \\
\text { kapan waktu bermain }\end{array}$ & 0,547 & 0,210 & Valid \\
\hline \multicolumn{4}{|c|}{ Kedisiplinan santri dalam menjalankan peraturan } \\
\hline 1 & $\begin{array}{l}\text { Saya tidak membawa handphone ketika } \\
\text { berada di pondok pesantren }\end{array}$ & 0,473 & 0,210 & Valid \\
\hline 2 & Saya bangun tidur sebelum masuk waktu & 0,508 & 0,210 & Valid \\
\hline
\end{tabular}




\begin{tabular}{|c|l|c|c|l|}
\hline & Subuh & & & \\
\hline 3 & $\begin{array}{l}\text { Saya selalu meminta izin ketika keluar } \\
\text { pondok pesantren }\end{array}$ & 0,675 & 0,210 & Valid \\
\hline 4 & $\begin{array}{l}\text { Saya mengetahui seluruh peraturan dalam } \\
\text { pondok pesantren }\end{array}$ & 0,374 & 0,210 & Valid \\
\hline 5 & $\begin{array}{l}\text { Saya mengikuti semua peraturan yang ada } \\
\text { dalam pondok pesantren }\end{array}$ & 0,654 & 0,210 & Valid \\
\hline 6 & $\begin{array}{l}\text { Saya datang tepat waktu ketika kegiatan } \\
\text { pondok pesantren dilaksanakan }\end{array}$ & 0,528 & 0,210 & Valid \\
\hline 7 & $\begin{array}{l}\text { Saya selalu tepat waktu melaksanakan } \\
\text { sholat }\end{array}$ & 0,641 & 0,210 & Valid \\
\hline 8 & $\begin{array}{l}\text { Saya melaksanakan peraturan pondok } \\
\text { pesantren dengan tertib }\end{array}$ & 0,718 & 0,210 & Valid \\
\hline 9 & $\begin{array}{l}\text { Saya bersungguh-sungguh dalam } \\
\text { menjalankan peraturan pondok pesantren }\end{array}$ & 0,679 & 0,210 & Valid \\
\hline 10 & $\begin{array}{l}\text { Saya tidak akan melanggar peraturan } \\
\text { pondok pesantren }\end{array}$ & 0,605 & 0,210 & Valid \\
\hline
\end{tabular}

Berdasarkan tabel 2 di atas, nilai Rhitung setiap butir isntrumen penelitian lebih besar dari pada nilai Rtabel, dimana nilai Rtabel sebesar 0,210. Oleh karena itu seluruh intrumen yang peneliti gunakan dalam penelitian ini seluruhnya dinyatakan valid.

\section{Uji Reliabilitas}

Hasil penelitian apabila terdapat kesamaan dengan data dalam waktu yang berbeda merupakan hasil penelitian yang reliabel. Instrument yang reliabel akan menghasilkan data yang sama apabila digunakan digunakan untuk berulang kali untuk mengukur objek yang sama. ${ }^{14}$

Berikut tabel hasil analisis uji reliabilitas yang penelliti dapatkan, uji reliabilitas ini menggunakan aplikasi IDM SPSS versi 26.0 for windows.

${ }^{14}$ Ibid. 


\section{Qo'id Afifudin, Waslah.}

Tabel 3. Hasil Pengujian reliabilitas Variabel X dan Variabel Y

\begin{tabular}{|l|l|l|l|l|}
\hline No & Variabel & Alpha & $\mathrm{R}_{\text {Tabel }}$ & Keterangan \\
\hline 1 & Kecerdasan Spiritual $(\mathrm{X})$ & 0,733 & 0,210 & Reliabel \\
\hline 2 & $\begin{array}{l}\text { Kedisiplinan santri dalam menjalankan } \\
\text { peraturan }(\mathrm{Y})\end{array}$ & 0,762 & 0,210 & Reliabel \\
\hline
\end{tabular}

Berdasarkan tabel 3 di atas, nilai alpha setiap variabel lebih besar daripada nilai $R_{\text {tabel, }}$ nilai alpha dari Kecerdasan Spiritual $(X)$ sebesar 0,733; nilai alpha Kedisiplinan Santri dalam Menjalankan Peraturan sebesar 0,762; dan nilai $R_{\text {tabel }}$ sebesar 0,210. Oleh karena itu, varibel yang peneliti gunakan dalam penelitian ini dinyatakan reliabel.

\section{Uji Hipotesis}

Uji hipotesis dilakukan untuk mengetahui ada atau tidaknya hubungan kecerdasan spiritual dengan kedisiplinan santri dalam menjalankan peraturan. Uji hipotesis yang digunakan dalam penelitian ini adalah analisis korelasi Product moment yang dihitung secara manual dan dibantu aplikasi SPSS versi 26.0 for windows.

$$
\begin{aligned}
& \mathrm{N}=87 \\
& \sum X^{2}=113403 \\
& \sum X=3121 \\
& \sum \mathrm{Y}^{2}=108684 \\
& \sum Y=3056 \\
& \sum X Y=110401
\end{aligned}
$$

Sehingga akan didapatkan hasil sebagai berikut:

$$
\begin{aligned}
& r_{x y}=\frac{n \sum x y-\left(\sum x\right)\left(\sum y\right)}{\sqrt{\left(n \sum x^{2}-(x)^{2}\right)\left(n \sum y^{2}-(y)^{2}\right)}} \\
& r_{x y}=\frac{87,110401-(3121,3056)}{\sqrt{\left(87,113403-(3121)^{2}\right)\left(87,108684-(3056)^{2}\right)}} \\
& r_{x y}=\frac{9604887-9537776}{\sqrt{(9866061-9740641)(9455508-9339136)}}
\end{aligned}
$$




$$
\begin{aligned}
& r_{x y}=\frac{67111}{\sqrt{125420,116372}} \\
& r_{x y}=\frac{67111}{\sqrt{14595376240}} \\
& r_{x y}=\frac{67111}{120811.3}=0,556
\end{aligned}
$$

\section{Hasil Analisis Data Menggunakan Aplikasi SPSS}

\begin{tabular}{llll} 
Correlations & \multicolumn{1}{c}{$\begin{array}{l}\text { Kecerdasan } \\
\text { Spiritual }\end{array}$} & $\begin{array}{l}\text { Kedisiplinan } \\
\text { Santri }\end{array}$ \\
\hline Kecerdasan Spiritual & Pearson Correlation & 1 & .556 \\
\cline { 2 - 4 } & Sig. (2-tailed) & & .000 \\
\cline { 2 - 4 } & $\mathrm{N}$ & 87 & 87 \\
\hline Kedisiplinan Santri & Pearson Correlation & .556 & 1 \\
\cline { 2 - 4 } & Sig. (2-tailed) & .000 & \\
\cline { 2 - 4 } & $\mathrm{N}$ & 87 & 87 \\
\hline${ }^{* *}$. Correlation is significant at the 0,01 level (2-tailed). &
\end{tabular}

Berdasarkan perhitungan analisis korelasi Product moment dan analisis data menggunakan menggunakan aplikasi SPSS di atas, hasil yang diperoleh sebesar 0,556. Dimana hasil tersebut lebih besar nilainya daripada nilai $R_{\text {tabel }}$ yang nilainya sebesar 0,210 . Karena hasilnya lebih besar nilainya daripada nilai $R_{\text {tabel, }}$ maka terdapat hubungan antara kecerdasan spiritual dengan kedisiplinan santri dalam menjalankan peraturan pondok pesantren.

\section{PEMBAHASAN}

Tingkat kecerdasan spiritual santri di pondok pesantren diukur melalui beberapa indikator diantaranya adalah mampu menyesuaikan diri dengan lingkungan, mampu mendorong dirinya untuk instropeksi diri dan tujuan hidup yang telah pasti. Ketiga indikator tersebut diukur melalui pernyataan pada angket yang telah disebarkan dan diisi oleh 87 responden yang selanjutnya dianalisis 


\section{Qo'id Afifudin, Waslah.}

melalui rumus mean. Berdasarkan pengukuran yang telah dilakukan oleh peneliti, hasilnya menunjukkan bahwa kecerdasan santri pondok pesantren tergolong pada kriteria tinggi yakni 35,9 sebagaimana telah dipaparkan pada analisis data diatas.

Kedisiplinan santri dalam menjalankan peraturan pondok pesantren diukur melalui beberapa indikator diantaranya adalah sikap taat dan tertib terhadap peraturan pondok pesantren, sikap taat dan teratur dalam mengikuti kegiatan di pondok pesantren dan kesungguhan hati dalam menjalankan peraturan di pondok pesantren. Ketiga indikator tersebut diukur melalui pernyataan pada angket yang telah disebarkan dan diisi oleh 87 responden yang selanjutnya dianalisis melalui rumus mean. Berdasarkan pengukuran yang telah dilakukan oleh peneliti, hasilnya menunjukkan bahwa kesadaran santri dalam menjalankan peraturan pondok pesantren tergolong pada kriteria tinggi yakni 35,1 sebagaimana telah dipaparkan pada analisis data diatas.

Hubungan antara Tingkat Kecerdasan Siritual dengan Kedisiplinan Santri dalam Menjalankan Peraturan Pondok Pesantren. Ada atau tidaknya hubungan antara tingkat kecerdasan spiritual dengan kedisiplinan santri dalam menjalankan peraturan di Pondok Pesantren dapat diketahui melalui perhitungan korelasi product moment. Berdasarkan perhitungan yang telah dilakukan, memberikan hasil bahwa Rhitung 0,556 lebih besar dari Rtabel 0,210. Sehingga Ha diterima yakni "terdapat hubungan antara tingkat kecerdasan spiritual dengan 
kedisiplinan santri dalam menjalankan peraturan Pondok Pesantren AlMasruriyyah Tebuireng Diwek Jombang".

\section{E. KESIMPULAN}

Berdasarkan hasil penelitian yang telah peneliti lakukan di pondok pesantren Al-Masruriyyah Tebuireng Diwek Jombang, dan berdasarkan tujuan penelitian yang telah ditetapkan, maka dapat diambil kesimpulan sebagai berikut:

Kecerdasan Spiritual Santri Pondok Pesantren. Berdasarkan hasil penelitian menunjukkan bahwa Kecerdasan Spiritual Santri pondok pesantren diperoleh hasil 35,9. Berdasarkan jumlah tersebut dapat disimpulkan bahwa ratarata dari Kecerdasan Spiritual Santri berada pada skor antara 30-40 dengan kriteria tinggi.

Kedisilinan Santri dalam menjalankan Peraturan. Berdasarkan hasil penelitian menunjukkan bahwa kedisiplinan santri dalam menjalankan peraturan diperoleh hasil 35,1. Berdasarkan jumlah tersebut dapat disimpulkan bahwa ratarata dari kedisiplinan santri dalam menjalankan peraturan berada pada skor antara 30-40 dengan kriteria tinggi.

Hubungan antara tingkat kecerdasan spiritual dengan kedisiplinan santri dalam menjalankan peraturan Pondok Pesantren. Berdasarkan perhitungan korelasi product moment yang telah dilakukan, dapat diketahui bahwa Rxy atau Rhitung dengan jumlah 0,556 lebih besar dari Rtabel, dengan demikian “terdapat hubungan antara tingkat kecerdasan spiritual dengan kedisiplinan santri dalam 


\section{Qo'id Afifudin, Waslah.}

menjalankan peraturan Pondok Pesantren Al-Masruriyyah Tebuireng Diwek Jombang". Hasil tersebut juga memiliki tingkat hubungan antara variabel $X$ dan $Y$ dengan kriteria yang sedang. Serta menghasilkan koefensi determinasi sebesar $31 \%$, yang artinya besarnya hubungan antara tingkat kecerdasan spiritual dengan kedisiplinan santri dalam menjalankan peraturan Pondok Pesantren adalah sebesar $31 \%$.

\section{F. DAFTAR PUSTAKA}

Darmadi, Hamid. Metode Penelitian Pendidikan. Bandung: CV. Alfabeta, 2011.

Mubarok, Muhammad Kusni, dan Waslah. "Hubungan Tingkat Kecerdasan Spiritual Dengan Kesadaran Santri Dalam Menjalankan Peraturan Pondok Pesantren Al Muhajirin 3 Bahrul 'Ulum Tambakberas Jombang." Journal of Education and Management Studies Universitas KH. A. Wahab Hasbullah Jombang Vol. 3, no. 4 (2020): 41-46.

Nasional, Departemen Pendidikan. Kamus Bahasa Indonesia. Jakarta: Pusat Bahasa, 2008.

Rahmawati, Ulfah. "Pengembangan Kecerdasan Spiritual Santri: Studi terhadap Kegiatan Keagamaan di Rumah TahfizQu Deresan Putri Yogyakarta." Jurnal Penelitian Vol. 10, no. 1 (2016): 97-124.

Riyanto, M. Okta. “Peraturan Pondok Pesantren.” 2015. Diakses 3 Maret 2021. http:/ /oktamansabo.blogspot.com/2015/06/peraturan-pondokpesantren.html.

Sagala, Syaiful. "Manajemen Dan Kepemimpinan Pendidikan Pondok Pesantren." Jurnal Tarbiyah 22, no. 2 (2015): 205-225.

Sugiyono. Metode Penelitian Pendidikan Pendekatan Kuantitatif, Kualitatif, dan RED. Cet. Ke 22. Bandung: CV. Alfabeta, 2015.

Sulastyaningrum, Rizky, Trisno Martono, dan Budi Wahyono. "Pengaruh Kecerdasan Intelektual, Kecerdasan Emosional, dan Kecerdasan Spiritual Terhadap Prestasi Belajar Mata Pelajaran Ekonomi Pada 
Hubungan Tingkat Kecerdasan Spiritual Dengan Kedisiplinan Santri....

Peserta Didik Kelas XI IPS di SMA Negeri 1 Bulu Tahun Ajaran 2017/2018." Jurnal Pendidikan Bisnis dan Ekonomi 4, no. 2 (2019): 1-19.

Syam, Aldo Redho. "Manajemen Pendidikan Kedisiplinan Santri Di Pondok Pesantren (Studi Kasus Di Pondok Modern Darussalam Gontor Ponorogo)." UIN Maulana Malik Ibrahim, 2015.

Zohar, Danah, dan Ian Marshall. SQ Kecerdasan Spiritual. Cet. XI. Bandung: PT. Mizan Pustaka, 2007. 
Qo'id Afifudin, Waslah. 